\title{
KEPATUHAN PASIEN TB PARU TERHADAP PENGGUNAAN OBAT TB PARU DI RSUD GUNUNG JATI KOTA CIREBON TAHUN 2017
}

\section{ADHERENCE OF PULMONARY TUBERCULOSIS PATIENTS ON USE OF TB DRUGS IN GUNUNG JATI HOSPITAL OF CIREBON CITY IN 2017}

\author{
Rinto Susilo, Aida Maftuhah, Nur Rahmi Hidayati \\ Sekolah Tinggi Farmasi Muhammadiyah Cirebon
}

Email:rintosusilo88@gmail.com

\begin{abstract}
ABSTRAK
Tuberkulosis (TB) Paru adalah penyakit menular langsung yang disebabkan oleh kuman Mycobacterium tuberculosis.Kepatuhan pasien dalam melakukan pengobatan merupakan salah satu faktor yang menentukan dalam keberhasilan terapi yang optimal, namun kepatuhan pasien dalam pengobatan TB Paru seringkali rendah.Penelitian ini bertujuan untuk mengetahui karakteristik pasien TB Paru, kepatuhan pasien minum obat TB paru dan hubungan antara karakteristik pasien terhadap kepatuhan minum obat di Klinik Paru RSUD Gunung Jati Kota Cirebon tahun 2017.Penelitian dilakukan dengan desain observasional dan dirancang secara prospektif. Instrumen penelitian menggunakan surat persetujuan pasien (Informed Concent), lembar pengambilan data yang merupakan data sekunder dan data primer yang diperoleh dengan cara wawancara langsung dari pasien menggunakan kuisioner kepatuhan minum obat terstuktur yaitu kuisioner Medication Adherence Report Scale (MARS). Data yang didapat, dianalisis secara dekskriptif dan analisis hubungan dengan SPSS 16. Hasil penelitian dari 103 responden yang didapat menunjukkan karakteristik pasien TB Paru di dominasi oleh perempuan sebesar 56,31\%, usia produktif sebesar 59,22\%, pendidikan SD sebesar 50,48\%, tidak bekerja sebesar 38,82\%, kebiasaan tidak merokok sebesar $93,20 \%$, lama pengobatan $<6$ bulan sebesar $68,93 \%$ dan tidak adanya penyakit penyerta sebesar 77,66\%. Sedangkan untuk kepatuhan pasien TB paru diklinik RSUD Gunung Jati Kota Cirebon didapat derajat kepatuhan tinggi sebesar 54,36 \%, derajat kepatuhan sedang sebesar 45,63\% dan kepatuhan rendah sebesar 0\%. Hasil ChiSquare test menunjukkan bahwa tidak ada hubungan antara karakteristik pasien usia, jenis kelamin, pekerjaan dan pendidikan terhadap kepatuhan minum obat TB Paru $(\mathrm{P}>0,05)$.
\end{abstract}

Kata kunci :Karakteristik Pasien,Kepatuhan, TB Paru, RSUD Gunung Jati

\begin{abstract}
Pulmonary Tuberculosis (TB) is a contagious disease directly caused by the bacteriaMycobacterium tuberculosis. Patient adherence in treatment is one of the decisive factors in optimal therapeutic efficacy, but patient adherence in the treatment of pulmonary tuberculosis is often low. This study aims to determine the characteristics of patients with pulmonary tuberculosis, patient adherence to take pulmonary TB drugs and the relationship
\end{abstract}


between the characteristics of patients on medication adherence at the Outpatien Gunung Jati Hospital Cirebon City in 2017. The study was conducted with an observational design and prospectively designed. The research instrument uses an informed consent letter, a data collection sheet that is secondary data and primary data obtained by direct interview from the patient using a questionnaire of medication adherence report scale (MARS). Data obtained, analyzed descriptively and relationship analysis with SPSS 16. Result of research from 103 respondents obtained showed characteristic of pulmonary TB patient dominated by woman equal to $56,31 \%$, productive age equal to $59,22 \%$, elementary education $50,48 \%$, not working for $38.82 \%$, no smoking habit $93,20 \%$, length of treatment $<6$ months equal to $68,93 \%$ and absence of comorbid disease equal to $77,66 \%$. While for patient adherence of pulmonary tuberculosis in outpatient Gunung Jati hospital in Cirebon City got high degree of adherence equal to $54,36 \%$, medium degree of adherenceequal to $45,63 \%$ and low degree of adherenceequal to $0 \%$. Chi Square test shows that there is no correlation between patient characteristics of age, sex, occupation and education on medication adherence of pulmonary tuberculosis $(\mathrm{P}>0,05)$.

Keywords : Patient Characteristics, Adherence, Pulmonary TB, RSUD Gunung Jati

\section{PENDAHULUAN}

Tuberkulosis (TB) sampai dengan saat ini masih merupakan salah satu masalah kesehatan masyarakat di dunia walaupun upaya penanggulangan TB telah dilaksanakan dibanyak negara sejak tahun 1995. Jumlah kasus TB di Indonesia menurut Laporan WHO tahun2015 diperkirakan ada 1juta kasus TB baru per tahun dan 63.000 kasus TB dengan HIV positif. Angka Notifikasi Kasus (Case Notification Rate / CNR) dari 324.539 kasus, diantaranya 314.965 adalah kasus baru. Secara nasional perkiraan prevalensi HIV di antara pasien TB diperkirakan sebesar 6,2 \%. Jumlah kasus TB dengan Resisten Obat (TB-RO) diperkirakan sebanyak 6700 kasus yang berasal dari 1,9\% kasus TB-RO dari kasus baru TB dan ada 12\% kasus TB-RO dari TB dengan pengobatan ulang (Kemenkes RI, 2016). Keteraturan berobat penyakit TB Paru merupakan faktor yang penting dalam keberhasilan pengobatan, hal ini sangat erat kaitannya dengan perilaku kesehatan pasien atau penderita TB Paru, mengidentifikasikan bahwa perilaku kesehatan dipengaruhi oleh faktor-faktor berikut ini, yaitu (1) faktor predisposisi misalnya umur, pendidikan, jenis kelamin, pengetahuan, sikap, keyakinan, nilai dan norma, (2) faktor pemungkin misalnya ketersediaan sumber daya, keterampilan, keterjangkauan, (3) faktor penguat misalnya sikap dan perilaku petugas kesehatan, keluarga, teman, orang tua dan lain-lain (Hiswani, 2015). Penelitian ini bertujuan untuk mengetahui karakteristik pasien, tingkat kepatuhan pasien dan hubungan antara faktor karakteristik pasien TB Paru terhadap tingkat kepatuhan minum obat TB Paru di RSUD Gunung Jati Kota Cirebon.

\section{METODE PENELITIAN}

Penelitian ini dilakukan di instalasi rawat jalan RSUD Gunung Jati Kota Cirebon yang bertujuan untuk mengetahui karakteristik pasien, tingkat kepatuhan pasien TB Paru dan hubungan antara karakteristik pasien TB Paru terhadap kepatuhan minum obat TB Paru. Penelitian ini merupakan penelitian observasional dengan pendekatan Cross sectional, dengan cara observasi atau pengumpulan data sekaligus pada saat yang sama. Pengambilan data dilakukan secara prospektif pada bulan Maret-Mei 2017.

\section{Alat dan Bahan}

Alat yang digunakan dalam penelitian ini adalah lembar informed consent, lembar data karakteristik pasien, kuesioner kepatuhan MARS dan lembar pengumpulan data. Populasi pada penelitian ini adalah seluruh pasien TB Paru yang sedang melakukan 
pengobatan TB Paru di Instalasi Rawat Jalan RSUD Gunung Jati Kota Cirebon tahun 2017. Sampel pada penelitian ini adalah seluruh pasien TB Paru yang sedang melakukan pengobatan TB Paru di Instalasi Rawat Jalan RSUD Gunung Jati Kota Cirebon tahun 2017 yang dihitung berdasarkan rumus slovin dan memenuhi kriteria inklusi eksklusi serta bersedia menjadi responden pada penelitian ini pada bulan Maret 2017.

\section{Jalannya Penelitian}

1. Instrumen Penelitian

Instrumen utama yang digunakan pada penelitian ini adalah lembar kuesioner. Kuesioner pada penelitian ini digunakan untuk mengungkap informasi tentang karakteristik pasien dan tingkat kepatuhan pasien minum obat TB Paru di RSUD Gunung Jati Kota Cirebon.

2. Teknik Pengambilan Data

Pengisian kuesioner merupakan metode yang digunakan untuk mengumpulkan data dengan cara memberikan pertanyaan tertutup yang ada pada lembar kuesioner kepada pasien yang sebelumnya telah mendapatkan penjelasan berkaitan dengan tujuan penelitian dan telah menandatangani persetujuan menjadi responden penelitian, sehingga diperoleh keterangan tentang karakterisitik pasien dan kepatuhan minum obat TB Paru.

\section{Analisis Data}

Data yang diperoleh diteliti kembali kelengkapannya, kemudian dilakukan analisis univariat dan bivariat dengan SPSS 16. Analisis Univariat untuk mengetahui frekuensi dari masingmasing variabel penelitian meliputi karakteristik pasien (jenis kelamin, usia, pendidikan, pekerjaan, kebiasaan merokok, lama pengobatan dan penyakit penyerta) dan tingkat kepatuhan pasien dalam menggunakan obat anti TB. Analisis bivariat (chi square test) untuk mengetahui hubungan karakteristik pasien terhadap kepatuhan pasien dalam menggunakan obat anti TB.

\section{HASIL DAN PEMBAHASAN}

\section{Gambaran Karakteristik Pasien TB Paru di Klinik Paru RSUD Gunung Jati Cirebon}

Karakteristik pasien berdasarkan jenis kelamin, usia, pendidikan, pekerjaan, riwayat merokok, lama pengobatan dan penyakit penyerta dapat dilihat pada tabel I.

Pasien tuberculosis yang bersedia menjadi responden penelitian berjumlah 103 orang. Hasil karakteristik pasien berdasarkan pada tabel I menurut jenis kelamin, jumlah terbanyak pasien berjenis kelamin perempuan yaitu sebesar 58 responden $(56,31 \%)$. Responden perempuan cenderung lebih banyak dibandingkan responden laki-laki. Menurut laporan WHO tahun 2015 ditingkat global diperkirakan 9,6 juta kasus sebagian besar adalah perempuan (Kemenkes, 2016). Berdasarkan usia, kelompok terbesar adalah kelompok usia produktif $(<55$ tahun) yaitu 61 responden $(59,22 \%)$. Hal ini sesuai dengan penelitian yang dilakukan oleh Departemen kesehatan pada tahun 2005 dimana kasus tuberculosis di Indonesia lebih banyak terjadi pada kelompok usia produktif yaitu sekitar 75\% (Depkes, 2008). Indonesia sendiri diperkirakan 75\% penderita TB paru adalah usia produktif yaitu usia 15-50 tahun (Depkes RI, 2007; Herryanto dkk., 2002). Berdasarkan tingkat pendidikan, kelompok terbesar adalah tamatan SD sebanyak 52 responden $(50,48 \%)$. Kelompok responden dengan karakteristik pekerjaan kelompok terbesar adalah tidak bekerja $(29,12 \%)$. Berdasarkan kebiasaan merokok, pasien TB Paru yang tidak merokok lebih banyak terkena TB Paru sebanyak 96 responden $(93,2 \%)$ dibandingkan pasien yang memiliki kebiasaan merokok sebanyak 7 responden (6,79\%). Berdasarkan lama pengobatan, kelompok terbanyak adalah pasien yang berobat kurang dari sama dengan 6 bulan terdapat 71 responden $(68,93 \%)$. 
Tabel I. Distribusi Pasien TB Paru Berdasarkan Karakteristik Pasien Di Klinik Paru RSUD Gunung Jati Kota Cirebon

\begin{tabular}{|c|c|c|}
\hline Karakteristik & Jumlah & Persentase \\
\hline \multicolumn{3}{|l|}{ Jenis Kelamin } \\
\hline $\mathrm{L}$ & 45 & $43,68 \%$ \\
\hline $\mathrm{P}$ & 58 & $56,31 \%$ \\
\hline Jumlah & 103 & $100,00 \%$ \\
\hline \multicolumn{3}{|l|}{ Usia (Tahun) } \\
\hline$<55$ Tahun & 61 & $59,22 \%$ \\
\hline$\geq 55$ Tahun & 42 & $40,77 \%$ \\
\hline Jumlah & 103 & $100,00 \%$ \\
\hline \multicolumn{3}{|l|}{ Pendidikan } \\
\hline Tidak sekolah & 8 & $7,76 \%$ \\
\hline SD & 52 & $50,48 \%$ \\
\hline SLTP & 16 & $15,53 \%$ \\
\hline SLTA & 23 & $22,33 \%$ \\
\hline S1 & 4 & $3,88 \%$ \\
\hline Jumlah & 103 & $100,00 \%$ \\
\hline \multicolumn{3}{|l|}{ Pekerjaan } \\
\hline Ibu Rumah Tangga & 10 & $9,70 \%$ \\
\hline Tidak Bekerja & 30 & $29,12 \%$ \\
\hline Swasta & 10 & $9,70 \%$ \\
\hline Wiraswasta & 15 & $14,56 \%$ \\
\hline Buruh & 14 & $13,59 \%$ \\
\hline Nelayan & 8 & $7,76 \%$ \\
\hline Tani & 10 & $9,70 \%$ \\
\hline Pelajar & 1 & $0,97 \%$ \\
\hline Guru & 5 & $4,85 \%$ \\
\hline Jumlah & 103 & $100,00 \%$ \\
\hline \multicolumn{3}{|l|}{ Kebiasaan merokok } \\
\hline Merokok & 7 & $6,79 \%$ \\
\hline Tidak Merokok & 96 & $93,20 \%$ \\
\hline Jumlah & 103 & $100,00 \%$ \\
\hline \multicolumn{3}{|l|}{ Lama Pengobatan } \\
\hline$<6$ bulan & 71 & $68,93 \%$ \\
\hline$\geq 6$ bulan & 32 & $31,06 \%$ \\
\hline Jumlah & 103 & $100,00 \%$ \\
\hline \multicolumn{3}{|l|}{ Penyakit Penyerta } \\
\hline Jantung & 16 & $15.53 \%$ \\
\hline Diabetes Melitus & 5 & $4.85 \%$ \\
\hline Hipertensi & 2 & $1,94 \%$ \\
\hline Lain-lain & 80 & $77,66 \%$ \\
\hline Jumlah & 103 & $100,00 \%$ \\
\hline
\end{tabular}




\section{Tingkat Kepatuhan Pasien dalam menggunakan Obat Anti TB (OAT)}

Pengolahan data terhadap nilai kepatuhan diperoleh dari skor jawaban kuesioner MARS secara keseluruhan yang terdiri dari 5 pertanyaan. Adapun total skor kepatuhan pasien TB paru yang mendapat pengobatan Obat Anti Tuberculosis di Klinik Paru RSUD Gunung Jati Kota Cirebon terlihat pada tabel II.

Tabel II. Derajat kepatuhan Pasien TB paru di Klinik Paru RSUD Gunung Jati Kota Cirebon

\begin{tabular}{lcc}
\hline Derajat Kepatuhan & Jumlah Pasien & Persentase \\
& & $54,36 \%$ \\
Tinggi & 56 & $45,63 \%$ \\
Sedang & 47 & $0 \%$ \\
Rendah & 0 & $100,00 \%$ \\
\hline Jumlah & 103 & \\
\hline
\end{tabular}

Tingkat kepatuhan pasien tuberculosis dari hasil penelitian ini berdasarkan kuesioner MARS terbagi menjadi 3 kelompok kategori kepatuhan, yaitu kepatuhan tinggi, sedang dan rendah. Berdasarkan hasil yang tersaji pada tabel II, kelompok terbesar berada pada tingkat kepatuhan tinggi dengan jumlah pasien sebanyak 56 responden $(54,36 \%)$. Berdasarkan hasil penelitian tersebut terlihat bahwa tingkat kepatuhan pasien TB Paru terhadap OAT di klinik Paru RSUD Gunung Jati Kota Cirebon dapat dikatakan baik karena memiliki kepatuhan yang tinggi dalam minum obat lebih dari $50 \%(54,36 \%)$, hal ini merupakan salah satu faktor yang dapat mendukung keberhasilan pengobatan pasien TB Paru di RSUD Gunung Jati Kota Cirebon.

\section{Hubungan Karakteristik Pasien terhadap Tingkat Kepatuhan Pasien dalam Menggunakan Obat Anti TB (OAT)}

Analisis Statistik univariat dengan uji Chi Square dilakukan untuk mengetahui ada tidaknya hubungan antara karakteristik pasien (jenis kelamin,usia, pendidikan dan pekerjaan) terhadap tingkat kepatuhan pasien dalam menggunakan OAT, Hasil uji chi square dapat dilihat pada tabel III.

Tabel III. Hasil Uji Chi Square antara karaktreristik pasien dengan usia,jenis kelamin, pekerjaan dan pendidikan

\begin{tabular}{lcc}
\hline Karakteristik & Signifikasi (Uji chi Square) & taraf kepercayaan 95\% \\
\hline Usia & 0,422 & Tidak ada Hubungan \\
\hline Jenis Kelamin & 0,231 & Tidak ada Hubungan \\
\hline Pekerjaan & 0,520 & Tidak ada Hubungan \\
\hline Pendidikan & 0,640 & Tidak ada Hubungan \\
\hline
\end{tabular}

Berdasarkan hasil uji Chi Square (tabel III), secara keseluruhan pasien TB Paru yang masuk dalam penelitian ini tidak ada hubungan yang bermakna antara karakteristik pasien terhadap kepatuhan minum obat TB Paru dengan nilai signifikansi usia $(0,422)$, jenis kelamin $(0,231)$, pekerjaan $(0,520)$, pendidikan $(0,640)(\mathrm{P}>0,05)$ di RSUD Gunung Jati Kota Cirebon, sehingga dapat disimpulkan bahwa tidak ada hubungan antara 
karakteristik pasien TB Paru terhadap kepatuhan minum obat TB Paru di RSUD Gunung Jati kota Cirebon.

\section{KESIMPULAN}

Berdasarkan hasilpenelitian pada 103 responden, karakteristik pasien TB Paru di dominasi oleh jenis kelamin perempuan sebesar 56,31\%, usia produktif sebesar 59,22\%, pendidikan SD sebesar 50,48\%, tidak bekerja sebesar 38,82\%, kebiasaan tidak merokok sebesar $93,20 \%$, lama pengobatan <6 bulan sebesar $68,93 \%$ dan tidak adanya penyakit penyerta sebesar $77,66 \%$. Sedangkan untuk kepatuhan pasien TB paru diklinik RSUD Gunung Jati Kota Cirebon sebagian besar berada pada derajat kepatuhan tinggi sebesar 54,36 $\%$. Hasil Chi Square test menunjukkan bahwa tidak ada hubungan antara karakteristik pasien usia, jenis kelamin, pekerjaan dan pendidikan terhadap kepatuhan minum obat TB Paru $(\mathrm{P}>0,05)$.

\section{DAFTAR PUSTAKA}

Amaliah, R. 2012. Faktof-faktor yang berhubungan dengan kegagalan konversi penderita TB paru BTA positif pengobatan fase intensif di Kabupaten Bekasi tahun 2010.Fakultas Kesehatan Masyarakat Universitas Indonesia

Departemen Kesehatan RI. 2008. Pedoman Nasional Penanggulangan Tuberkulosis, Jakarta : Gedurnas TB. Edisi 2 hal. 4-6

Herryanto, 2002.Pengaruh Penyuluhan Terhadap Pengetahuan Penderita Tuberkulosis Paru di Kabupaten Tanggerang. Jurnal Ekologi Kesehatan Vol. 2 2003.3 : 282-289

Hiswani. 2015. Penyebab, Pencegahan dan Pengobatan TB Paru. Jakarta : Puspas Swara.

Kementerian Kesehatan Republik Indonesia.2016. Penanggulangan Tuberkulosis. Jakarta : Kemenkes RI

Molloy et al. 2012. Type Dpersonality, Self-efficacy and medication adherence followingan acute coronary syndrom. Psychosom Med 74 (1):100-106

Nadesul, Hendrawan. 2006. Penyebab, Pencegahan dan Pengobatan TB Paru. Jakarta : Puspas Swara.

Notoatmodjo,S. 2014. Pengantar Ilmu Perilaku Kesehatan, Badan Penerbit Kesehatan Masyarakat Universitas Indonesia, Jakarta

Suharmiati dan Maryani, H. 2011. Analisis hubungan penggunaan obat FDC/Kombipak pada penderita yang didiagnosis TB paru berdasarkan karakteristik. Buletin Penelitian Sistem Kesehatan Vol. 14, No.2. 